\title{
BORROWING CONSTRAINTS AND THE TENURE CHOICE OF YOUNG HOUSEHOLDS
}

Donald R. Haurin

Patric H. Hendershott

Susan M. Wachter

Working Paper 5630

\section{NATIONAL BUREAU OF ECONOMIC RESEARCH 1050 Massachusetts Avenue \\ Cambridge, MA 02138 June 1996}

Research assistance was supplied by Min Seok Yang and Woo Hyung Yang. Funding was provided by Fannie Mae. We wish to also thank Daniel Feenberg of NBER for his assistance with the TAXSIM program. This paper is part of NBER's research program in Public Economics. Any opinions expressed are those of the authors and not those of the National Bureau of Economic Research.

(C) 1996 by Donald R. Haurin, Patric H. Hendershott and Susan M. Wachter. All rights reserved. Short sections of text, not to exceed two paragraphs, may be quoted without explicit permission provided that full credit, including $(\mathcal{C}$ notice, is given to the source. 


\title{
BORROWING CONSTRAINTS AND THE TENURE CHOICE OF YOUNG HOUSEHOLDS
}

\begin{abstract}
In this paper we analyze the factors that affect the tenure choice of young adults, highlighting the impact of mortgage lender imposed borrowing constraints. The data set is a panel of youth age 20-33 for the years 1985-90. Our methods differ from most prior studies in many ways including consideration of possible sample selection bias, a richer model of the stochastic error structure, better measurement of which households are bound by borrowing constraints, and a fuller consideration of the endogeneity of wealth and income. Once all changes are implemented, we find ownership tendencies to be quite sensitive to economic variables. Specifically, potential earnings, the relative cost of owning a home, and especially borrowing constraints affect the tendency to own a home. In our sample of youth, $37 \%$ of households are constrained even after choosing their loan-to-value ratio to minimize the impact of the separate wealth and income requirements. The constraints reduce the probability of ownership of these households by 10 to 20 percentage points (a third to a half) depending on the particular characteristics of the household.

Donald R. Haurin

Department of Economics

Derby Hall

154 N Oval Mall

Ohio State University

Columbus, $\mathrm{OH} 43210$

Patrick H. Hendershott

Department of Finance

Hagerty Hall

1775 College Road

Ohio State University

Columbus, $\mathrm{OH} 43210$

and NBER

Susan M. Wachter Finance Department University of Pennsylvania Philadelphia, PA 19104
\end{abstract}




\section{INTRODUCTION}

Tenure choice has been conventionally viewed as determined by three factors: permanent income, the cost of owning relative to renting, and household life-cycle attributes (Rosen, 1985). Permanent income (both long term earnings capacity and income from nonhuman capital), rather than current income, is important because tenure choice and housing consumption are long term decisions. $^{1}$ A series of papers published in 1989 added lender borrowing constraints as a determinant (Jones, 1989, Linneman and Wachter, 1989, and Zorn, 1989). Owing to information asymmetries and moral hazard, lenders base borrowing capacity on measurable current income and liquid assets rather than future income and total wealth. Liquid assets are important because lenders require equity contributions of borrowers. The importance of liquid wealth for a down payment is conceptually distinct from its effect through permanent income or total wealth inclusive of human capital. Whether the liquid wealth constraint is an important factor in tenure choice, separately from permanent income, must be empirically determined. That these factors are distinct, however, is conceptually clear.

In this paper we analyze the factors that affect the tenure choice of young adults, extending earlier work to include intertemporal data. We focus on the group making the transition to homeownership; the data set is a panel of youth age 20-33 for the years 1985-90. The issue of constraints is likely to be far more relevant for these households than for established older households. Our methods differ from most prior studies in many ways including consideration of possible sample selection bias, a richer model of the stochastic error structure, better measurement of which households are bound by borrowing constraints, and a fuller consideration of the endogeneity of wealth and income. 
The paper is structured as follows. We first review the 1989 papers and more recent contributions. In Sections III and IV we discuss the data and our innovations to modeling the tenure decision. We report the results in Section $\mathrm{V}$ and then conclude.

\section{RECENT STUDIES}

Linneman and Wachter (hereafter L-W) use micro data to quantify the impact of income and wealth constraint measures on individual homeownership propensities. The measures are based on the requirements for mortgages that qualify for purchase by the Federal Home Loan Mortgage Corporation and the Federal National Mortgage Association, which set industry standards. L-W first estimate the value of the desired home using a sample of unconstrained homeowners, defined as those having purchased a home whose value is less than $85 \%$ of the maximum value allowed by both the income and wealth constraints. Desired house value is calculated for the rest of their sample using the coefficients estimated from the sample of unconstrained owners $\left(\mathrm{V}^{*}\right)$. Knowledge of a household's current income, wealth, and desired home purchase price allows, L-W to measure the extent that a household's desired purchase price exceeds the maximum home purchase price that would satisfy industry borrowing standards.

L-W formulate six constraint measures, three each for income and wealth. For wealth (W), two dummy variables indicate whether the household is highly constrained or moderately constrained. They define the maximum house purchase price allowable under the wealth constraint as:

$$
\mathrm{V}^{\mathrm{w}}=\mathrm{W} /\left(1-\mathrm{LTV}^{*}\right)
$$


where LTV* is the maximum LTV allowed by lenders. If desired house value is greater than $\mathrm{V}^{\mathrm{w}}$, then the household is defined to be highly wealth constrained. If desired house value is between $90 \%$ and $100 \%$ of $\mathrm{V}^{\mathrm{w}}$, then the household is moderately wealth constrained. That is, if

$$
\begin{array}{ll}
\mathrm{V}^{\mathrm{w}} \leq \mathrm{V}^{*}, & \text { then Wealth Gap-High }=1, \text { else Wealth Gap-High }=0 \\
\mathrm{~V}^{\mathrm{w}}>\mathrm{V}^{*} \geq 0.9 \mathrm{~V}^{\mathrm{w},} & \text { then Wealth Gap-Moderate }=1, \text { else Wealth Gap-Moderate }=0
\end{array}
$$

The third variable is the difference between the desired and constrained house values for highly constrained households:

$$
\text { Wealth Gap-\$ Shortage }=\left(\mathrm{V}^{*}-\mathrm{V}^{\mathrm{W}}\right) *(\text { Wealth Gap-High })
$$

The expected coefficient signs of all three variables when entered in the tenure choice equation are negative.

The three income constraints are similarly defined. The maximum house purchase price allowable under the current income (y) constraint is:

$$
\mathrm{V}^{\mathrm{I}}=0.28 \mathrm{y} / \mathrm{rLTV}^{*}
$$

where $\mathrm{r}$ is the interest rate and the 0.28 reflects the lender constraint that the loan payment cannot exceed 28 percent of income (the loan payment is interest only). Two dummy variables (Income Gap-High and Income Gap-Moderate) and a continuous variable (Income Gap-\$ Shortage) are 
defined in the same way as for the wealth constraints. L-W set LTV* equal to 0.8 .

The probability of homeownership is estimated for recent movers using data from two periods: 1975 to 1979 , and 1981 to 1983 . To provide a baseline for comparison with traditional specifications, the model was also estimated excluding borrowing constraint variables. Including borrowing constraints markedly improved the fit of the model for both sample periods and substantially reduced the estimated impact of household income and age. The wealth constraint variables had larger impacts than the income variables. Their research indicated that even in welldeveloped capital markets, the presence of borrowing constraints, particularly the wealth constraint, negatively affects homeownership propensities.

Zorn (1989) tested a model of tenure choice based on utility maximization over three options: maintain current housing, move to owned residence, or move to rental housing using data on 4000 households surveyed in May 1986 by the Joint Center for Housing Studies. Rather than treating the income and wealth constraints separately, he measured the extent to which the constraints bind as the difference between the desired house value and the minimum value allowed under the more binding of the two constraints, again assuming an 80 percent loan-to-value ratio. Because borrowing constraints limit the quantity of housing that households are able to acquire as owners, he argued that the tenure-choice decision is driven not by the traditional ratio of the costs of owning and renting, but by an assessment of the level of utility attainable from the overall consumption bundle of housing and non-housing goods selected under each tenure alternative. His data supported the hypothesis that movement to owned housing is less likely than the other options when estimated household income and wealth constraints bind.

LaFayette, Haurin, and Hendershott (1995) follow Zorn in that they measured the extent to 
which households were constrained using the more binding of the income and wealth constraints and they assessed the level of utility attainable from the overall consumption bundle. Their innovation is allowing households to select the loan-to-value ratio and mortgage product that minimizes the constraint. $^{2}$ To illustrate the LTV decision, for most households the constraint is minimized by selecting the LTV that equates the two constraint values. The result is

$$
\mathrm{LTV}^{*}=0.28 \mathrm{y} /(0.28 \mathrm{y}+\mathrm{rW})
$$

Allowing for mortgage and LTV choice reduces the fraction of recently moving households estimated to be constrained by about a third.

The potential importance of wealth to tenure choice has also been considered by Jones (1989). Using a Canadian data set, he finds that current net worth plays a far more important role than human capital in triggering home ownership. A model highlighting the importance of current wealth argues that if the lender imposed wealth constraint is unavoidable, then all new homeowners will have current net wealth sufficient to make the down payment on their purchased house. Also, if ownership is the desired tenure choice for all households and only the wealth constraint prohibits some from owming, then all renters will have wealth less than that required by the constraint. Thus, the outcome of a comparison of current wealth and the minimal amount required to meet the lending constraint for the desired house will predict homeownership perfectly.

However, current wealth is not an exogenous variable in a household's multiperiod choice of whether or when to become a homeowner. Rather, annual savings decisions determine wealth, and saving is partly determined by a household's choice of labor supply and expenditures (other 
factors include wage rates, gifts, and inheritances). In fact, the desire to become a homeowner is likely a major determinant of wealth accumulation of youth (Haurin, Hendershott, and Wachter, 1996b). This argument suggests that tests of the importance of mortgage lender constraints on tenure choice must allow wealth and the indicator of whether the wealth constraint is binding to be endogenous, unlike Jones' treatment of it as exogenous. ${ }^{3}$ Because ownership intentions are influenced by the ability of the household to save, cross-sectional data are not likely to enable an analyst to sort out the causal structure between saving and homeownership. The availability of intertemporal data should allow a better understanding of this linkage.

\section{DATA}

Our primary data set is the National Longitudinal Survey of Youth (NLSY), housed at the Center for Human Resource Research (CHRR) at the Ohio State University. Although it is collected annually dating from 1979, wealth is reported beginning only in 1985 . The survey has an excellent retention rate ( $90 \%$ or higher). The method of collecting data is reported in the NLS Handbook of the Center for Human Resource Research (1993). Respondents were age 14-21 in 1979; thus, our study from 1985 to 1990 includes youth ages 20 to 32 . During these ages, youth are saving toward their first home purchase, a critical time for our study.

A detailed description of the data set is contained in Haurin, Hendershott, and Wachter (H-HW, 1996a). In that study, we tested the reliability of the wealth data by comparing it with the Survey of Consumer Finances and found it to be comparable. Also, we compared the reported home ownership rates in the NLSY to those in the American Housing Survey and again found good comparability. Other variables in our study have been tested and found to be reliable, these reports 
summarized in H-H-W (1996a). The means of variables used in our study are listed in Table 1. All nominal data are deflated.

One positive aspect of the panel data is that the intertemporal consistency of a respondent's data can be checked, outliers identified and deleted or corrected if other corroborative information is present. The resulting data set is superior to a single cross-section in terms of accuracy of measurement. Another positive aspect is that respondent specific unobserved variables can be accounted for in the error structure of the econometric model.

An important variable not present in the NLSY is the cost of constant-quality housing. This measure is a component of the owner cost of housing and the relative owner-renter cost. We use the Fannie Mae-Freddie Mac repeat sales house price index because it has wide spatial coverage and is available for 1985-90. This series has good correlation with other series such as Coldwell Bank, the series reported in Haurin, Hendershott, and Kim (1991), and the American Chamber of Commerce series (see H-H-W 1996a). Because the repeat sales series is an index, we need a single cross section of house price levels to obtain level data. We use the 1987 American Chamber of Commerce data (ACCRA 1987).

\section{TENURE CHOICE AND LENDER CONSTRAINTS}

We reconsider and extend the L-W method of analysis of the impact of lender constraints on tenure choice. The extensions include better measurement of desired house value, the use of exogenous proxies for permanent income, the treatment of wealth as endogenous, allowance for endogenous loan-to-value choice, and a superior econometric technique. Below, we discuss each modification. 


\section{Desired House Value}

The measurement of the constraint variables requires measurement of the value of the house that would be purchased if there were no mortgage lender constraints. L-W's measurement technique uses a sample restricted to unconstrained owners to estimate desired house value for all households. However, this sample of unconstrained households may be selective and if so, the resulting estimation of house value on household characteristics and house price would not be applicable to constrained homeowners and renters. For example, it is possible that the sample of unconstrained owners consists of households that have a taste for atypically small houses. The predicted value of the desired house value should be derived using a method that corrects for possible sample selection bias such as the Heckman two-step correction technique (1979).

We applied the Heckman method to our longitudinal sample and found no evidence of sample selection bias. ${ }^{4}$ Thus, our method of deriving the desired house value is an OLS regression of the log of house value on a set of household characteristics and the cost of owned housing using a sample of unconstrained owners. The results are reported in column 1 of Table A-1. Explanatory variables replicate the L-W set and include age, marriage, family size, gender, Black, Hispanic, permanent income, central city location, suburban location, whether in an MSA, three regional variables, and the log of the owner cost of housing. Permanent income and the owner cost of housing are based on standard formulations (Goodman and Kawai 1982; Hendershott and Shilling 1982). ${ }^{5}$ In the estimation of desired house value, we find that the most significant factors are permanent income, age, race/ethnicity, marriage, central city location, and regional location. 


\section{Permanent Income and Wages}

The concept of permanent income is only valid if labor supply is fixed (Killingsworth 1983). For youth, this assumption is not appropriate. Thus we replace permanent income with a measure of the wage a youth could earn if employed full time (potential wage), this variable being independent of other endogenous choices such as labor supply or living arrangement (Haurin, Hendershott, and Kim, 1994). We predict wages separately for respondent and spouse (if present). The estimation cannot be limited to full time working youth because of the possibility of selection bias. We found that estimation results best conform to expectations when we use a tobit model on the full sample. Explanatory variables include age, highest grade completed, an achievement test score, gender, race/ethnicity, and health. For the respondent, all variables are significant at the $5 \%$ level except for age and education level-squared. The most significant are the achievement test score, gender, and race/ethnicity. The results for spouses are not as good, but the sample of positive wage observations is much smaller. Results are reported in columns 2 and 3 of Table A-1.

\section{Endogenous Wealth}

The wealth and constraint variables should be treated as endogenous to account for youth simultaneously determining tenure status and savings. This modification requires a 2SLS approach be used to create an instrumental variable for wealth. Our longitudinal data set allows us to test a random effects model that allows for autocorrelation. The model is:

$$
\mathrm{W}_{\mathrm{it}}=\alpha+\beta^{\prime} Z_{\mathrm{it}}+v_{\mathrm{i}}+\epsilon_{\mathrm{it}}
$$




$$
\begin{aligned}
& \epsilon_{i t}=\rho \epsilon_{i, t-1}+\eta_{i t} \\
& \mathrm{E}\left[v_{i}\right]=0, \operatorname{Var}\left[v_{i}\right]=\sigma_{u}{ }^{2}, \operatorname{Cov}\left[\epsilon_{i t}, v_{i}\right]=0, \\
& \operatorname{Var}\left[\epsilon_{i t}+v_{i}\right]=\sigma^{2}=\sigma_{u}{ }^{2}+\sigma_{\epsilon}{ }^{2}, \quad \operatorname{Cor}\left[\epsilon_{i t}+v_{i}, \epsilon_{i s}+v_{i}\right]=\sigma_{u}{ }^{2} / \sigma^{2} .
\end{aligned}
$$

In equation (6), wealth is a function of the explanatory variables $Z$, a household specific random error $v_{\mathbf{i}}$, and a random error $\epsilon_{\mathrm{it}}$. This latter term is allowed to be autocorrelated as described in (7). The estimation method is generalized least squares. ${ }^{6}$

Results of the wealth estimation are reported in column 4 of Table A-1. Identification is achieved by inclusion of a number of variables such as the total number of years married, gifts from relatives, and parental education level. Gifts, number of years married, highest grade completed, and age are the most significant variables. A Lagrange multiplier test of this model versus the alternative of a nonautocorrelated classical regression model yields a Lagrange multipler statistic of 1802 , this being highly significant. The intertemporal correlation of household specific residuals is estimated to be 0.5 . The autocorrelation ( $\rho$ in eqn. 7 ) is only -0.05 . The predicted value of wealth derived from this estimation is then used in the derivation of the constraint variables described in equations (2) and (3).

\section{Measurement of the Income and Wealth Constraints}

The L-W method yields a total of six measures of the tightness of the lender imposed income and wealth constraints. We halve the number of variables to three by accounting for a household's optimal adjustment to the income and wealth constraints. As explained in Hendershott, LaFayette, and Haurin (1996) and LaFayette, Haurin, and Hendershott (1995), a 
household falls into one of three categories: it is either unconstrained by the lender requirements regarding current income and wealth, constrained by one of the two requirements, or constrained by both. If bound by only one constraint when the loan-to-value ratio (LTV) is 0.8 , a household will move away from the $0.8 \mathrm{LTV}$ to loosen the binding constraint even though this action tightens the nonbinding constraint. LTV is modified until one of three cases occurs: the household is constrained by neither requirement, both constraints are equally binding in terms of how much housing can be purchased, or the household faces a limiting case such as being unable to obtain a loan for less than a $5 \%$ down payment. In the first case, the constraints are zero. In the other two cases, we determine the optimal LTV by finding the value that makes the constraints equally binding with the requirement that LTV be no greater than 0.95 (see equ 5). In these cases, some households who were judged highly constrained by L-W's method become moderately constrained, and their measure of the wealth or income shortfall decreases.

We report the percentage of constrained households in Table 2. L-W's reported percentages of constrained households depend on the time period. During 1981-83, they find that $27 \%$ of households are highly income constrained and $40 \%$ are highly wealth constrained. Those moderately constrained are $6 \%$ and $1 \%$ respectively. When we replicate L-W's method and definitions of the constraints, we find that the percentage of highly income constrained households is nearly identical (28\%), but the percentage highly wealth constrained is much higher (58\%) as expected given our younger sample. About five percent of young households are moderately constrained. When households select the optimal LTV, we expect the most binding constraint to be loosened. This expectation is confirmed because the average LTV rises to 0.85 , resulting in only $37 \%$ being highly constrained by either income or wealth. ${ }^{7}$ Moderately 
constrained household now equal $6 \%$ of the sample. ${ }^{8}$

\section{Model of Tenure Choice}

The tendency to own a home is assumed to have the general form:

$$
\mathrm{O}_{\mathrm{it}}=\beta_{\mathrm{x}}{ }^{\prime} \mathrm{X}_{\mathrm{it}}+\mu_{\mathrm{i}}+v_{\mathrm{it}}
$$

The explanatory variables included in $\mathrm{X}$ are the potential wage, cost of owning relative to

renting ${ }^{9}$, race/ethnicity, family size, marital status, expected length of tenancy, and a vector of wealth/income mortgage constraint measures. We do not observe the tendency to own; rather, we observe the result of the discrete choice of whether to own or rent.

The error structure in the tendency to own equation contains the usual random component and a person specific random error $\mu_{\mathrm{i}}$, a generalization of the typical cross-sectional approach. The complete error structure is:

$$
\begin{aligned}
& \operatorname{Var}\left(\mu_{\mathrm{i}}+v_{\mathrm{it}}\right) \equiv \operatorname{Var}\left(\epsilon_{\mathrm{it}}\right)=\sigma_{\mu}{ }^{2}+\sigma_{v}{ }^{2} \\
& \operatorname{Corr}^{2}\left(\epsilon_{i \mathrm{t}}, \epsilon_{\mathrm{is}}\right) \equiv \rho^{2}=\sigma_{\mu}{ }^{2} /\left(\sigma_{\mu}{ }^{2}+\sigma_{v}{ }^{2}\right) .
\end{aligned}
$$

The likelihood function and details of the estimation are in Butler and Moffitt (1982). ${ }^{10} \mathrm{~A}$ significant $\rho$ indicates that the household specific stochastic errors are correlated over time, in which case a simple probit approach applied to the entire panel of data would be inappropriate. This structure addresses the problem of unobserved heterogeneity that results from omitted variables, an approach possible only with a panel data set. 


\section{RESULTS}

Our first task is to replicate the estimation method and variables of L-W (1989), thus confirming their original study and deriving a baseline against which to compare the new results. Although our source of data differs from L-W, most of their explanatory variables are available or can be created from the NLSY. The dependent variable is an indicator of whether the respondent is a homeowner. L-W's explanatory variables are demographic (Black, Hispanic, family size, married, and age of head) and economic (permanent income, cost of homeowning relative to renting, expected duration of tenancy, and a series of indicators of mortgage lender constraints). ${ }^{11}$ Differences between our baseline case and L-W include our use of a longitudinal data set rather than a cross-section, use of probit rather than logit, and treatment of age as continuous given the limited age range of our respondents rather than splitting age of head into seven categories. Initially, although our sample is longitudinal, we simply pool the data and do not account for intertemporal correlation of household specific residuals.

Given that the data sets cover different periods and contain different ages of household head (ours is limited to young adults while L-W include the entire age spectrum), it would not be surprising if estimation results differed. The comparison of their outcomes for $1975-77$ and 1981-83 to our result is reported in Table 3 where we find substantial similarity. Whenever an economic variable is significant in L-W, it is significant in our estimation and, in a few cases, we find additional coefficients are significant and have the sign predicted by theory. Coefficients of some demographic variables differ (e.g., family size and Black), perhaps explained by the much lower average age in our sample. A comparison of the key elasticities of ownership tendencies also yields the conclusion that our baseline findings are similar to those of $\mathrm{L}-\mathrm{W}$ when their 
method is replicated. For example, the elasticity of homeownership with respect to the relative cost of owning is estimated to be -0.93 by L-W compared with our estimate of -1.25 . Estimates of the elasticity of ownership with respect to permanent income are 0.37 and 0.31 respectively. We conclude that use of L-W's methodology on a different data set yields generally similar findings.

We next execute the improvements discussed previously and determine whether any of the baseline results change. Table 4 lists our baseline estimates in the first column of results. ${ }^{12}$ In the next column we replace income with two wage variables, we replace the six constraint variables with three, and we replace observed wealth with an instrumental variable. However, we do not impose the random effects model of the stochastic errors. Significant effects are found for respondent's and spouse's potential wages, the relative cost of owning, indicators of whether the household is highly or moderately constrained and marriage. All these coefficients have the expected signs.

In the final column we report the results of the random effects estimation where we find the estimate of period to period error correlation is 0.73 , this being highly significant. ${ }^{13}$ Thus, we find evidence that there are omitted variables in the tenure choice estimation. Lender constraints reduce the probability of owning for both highly and moderately constrained households. The coefficient of the variable indicating the household is highly constrained is only one-third that of the coefficient of the separate wealth constraint (compare coefficients in column 1 with column 3 ), but it is slightly greater than that of the income constraint. A similar pattern holds for moderately constrained households.

The impact of being highly constrained on the probability of ownership depends on the 
values of the other explanatory variables. Our example is for a 30 year old white married couple with one child having average wages, relative cost of owning, and expected length of tenancy. The probability of owning a home is 0.20 if the household is unconstrained. If constrained, the probability of owning falls to about 0.10 . Instead, if wages equal $\$ 10$ hourly for both respondent and spouse rather than the mean of about $\$ 7$, the probability of owning is 0.52 if unconstrained. If constrained, the probability falls substantially to $0.34 .^{14}$ We find that the variable measuring the housing shortfall created by the lender constraints (i.e., the strength of the lender constraint) has no significant separate impact on the tenure decision; rather, the two dummy variables explain the total impact.

Other significant explanatory variables include the cost of owning, respondent's and spouse's wage rates, expected length of tenancy, and marriage. The resultant reduction in the annualized expected transaction cost of selling caused by longer expected tenancy increases the likelihood of ownership. Marriage also raises the probability of homeownership, this effect observed although household wealth and potential wages are controlled. We find no effect of family size or the race/ethnicity indicators. Increased age has a marginally significant positive effect on the tendency to own a home.

The random effects approach changes many coefficient values compared with the case where $\rho$ is constrained to be zero (column 2). Coefficients for respondent's wage and age double, that of marriage increases by $50 \%$, that of spouse's wage rises by $40 \%$, that of expected length of tenancy rises by a factor of six, that of relative cost rises in absolute value by $240 \%$, and that for the highly constrained indicator falls by $30 \%$. Overall, the coefficients in the random effects estimation are larger suggesting that young households are more sensitive to 
changes in explanatory variables. Elasticity estimates of the ownership tendency are 0.5 with respect to wages, -1.4 for relative costs, 0.5 for expected length of tenancy, and 0.9 for age. As noted above, if borrowing requirements are binding, the tendency to own is substantially reduced.

\section{CONCLUSIONS}

Three 1989 papers provided the first evidence that lender imposed borrowing constraints adversely affect home ownership propensities. Our study builds on these by using a data set restricted to young households, who are most likely to be constrained, and making a number of improvements to their methods. We find that borrowing constraints significantly reduce the tendency toward ownership.

Our methods differ from these studies in five ways. First, because household saving is clearly a choice variable for young households (Haurin, Hendershott, and Wachter 1996a), household wealth is simultaneously determined with tenure choice. We use an instrumental variable approach to address this concern, endogenizing our measure of borrowing constraint severity. Second, we consider the problem of sample selection bias in the estimation of a household's desired amount of housing, this being an input to the borrowing constraint measures. However, we find no evidence of selection bias in our sample. Third, we reject the use of permanent income in the tenure choice equation because income depends on labor supply which is clearly jointly determined (Haurin, Hendershott and Kim, 1994). Instead, we use an estimate of wages earned if employed full time and find that increases in either respondent's or spouse's wages raise their propensity to become a homeowner. Fourth, our sample is a panel 
data set. Panel data allow us to estimate a richer error structure where we test for household specific random errors that are correlated over time. We find that the correlation of errors is highly significant and large, 0.73 . Accounting for this correlation has a substantial impact on explanatory variables' coefficients in the tenure choice model, generally increasing their size. Fifth, we allow households to minimize the impact of income and wealth constraints by optimizing their loan-to-value ratio (Hendershott, LaFayette, and Haurin, 1996). This change substantially reduces the estimated number of households facing a binding constraint.

Our first step in the estimation is to replicate Linneman and Wachters results, but with a sample of younger households. In spite of this difference in data, similar results are obtained if a similar estimation method is used. This finding allows us to identify differences resulting from the five changes in estimation technique.

In our preferred model, we find that the tendency toward owning a home is sensitive to a household's earning capacity as measured by wage rates. Ownership propensities also depend on the cost of owning relative to renting, age, marital status, and the expected length of tenancy. Compared to L-W, our estimates of the responsiveness of ownership to these variables is larger and generally have a higher level of statistical significance.

We address the question of whether binding borrowing constraints influence home ownership probabilities. We find that if a household is constrained or very nearly constrained because of low current income or wealth, then its probability of owning is substantially reduced. The reduction depends on the values of other explanatory variables. We give two examples: if the unconstrained probability of owning is 0.2 , the imposition of a borrowing constraint reduces the likelihood of owning by half. If the unconstrained probability is 0.5 , the reduction in 
probability of owning is a third.

An interesting finding is that if a household faces a binding constraint, there is no additional effect on the tendency to own if the shortfall in current wealth or income is increased. That is, our results suggest marginally constrained households are no more likely to own than severely constrained households. That is, households do not downsize the desired size of an owned property until it is no longer constrained, a result consistent with the findings of LaFayette, Haurin, and Hendershott (1995). Also, the policy implication is that intervention to reduce the severity of the constraint faced by households will not affect homeownership unless the intervention eliminates the constraint. 


\section{REFERENCES}

ACCRA (formerly American Chamber of Commerce Researchers Association). 1987. Cost of Living Index, Louisville, KY.

Butler, J. and Robert Moffitt. 1982. A Computationally Efficient Quadrature Procedure for the One Factor Multinomial Probit Model. Econometrica 50(3): 761-764.

Capozza, Dennis, Richard Green, and Patric Hendershott. 1996. Taxes, Mortgage Borrowing and Residential Land Prices. In Henry Aaron and Willian Gale, editors, The Economic Effects of Fundamental Tax Reform. The Brookings Institution.

Center for Human Resource Research. 1993. NLS Handbook. Columbus OH: Ohio State University.

Goodman, Allen and Masahiro Kawai. 1982. Permanent Income, Hedonic Prices, and Demand for Housing: New Evidence. Journal of Urban Economics. 12: 214-237.

Haurin, Donald, Patric Hendershott, and Dongwook Kim. 1991. Local House Price Indexes: 1982-1991. Journal of the American Real Estate and Urban Economics Association 19(3): 451472.

Haurin, Donald, Patric Hendershott, and Dongwook Kim. 1994. Housing Decisions of American Youth. Journal of Urban Economics 24 (January): 28-45.

Haurin, Donald, Patric Hendershott, and Susan Wachter. 1996a. Wealth Accumulation and Housing Choices of Young Households: An Exploratory Investigation. Journal of Housing Research 7(1): forthcoming.

Haurin, Donald, Patric Hendershott, and Susan Wachter. 1996b. Expected Home Ownership and Real Wealth Accumulation of Youth, June.

Heckman, James. 1979. Sample Selection Bias as a Specification Error. Econometrica 47:153161.

Hendershott, Patric, William LaFayette, and Donald Haurin. 1996. Debt Usage and Mortgage Choice: Sensitivity to Default Insurance Costs. Journal of Urban Economics, forthcoming.

Hendershott, Patric and James Shilling. 1982. The Economics of Tenure Choice, 1955-79. In C.F. Sirmans, editor, Research in Real Estate 1: 105-133.

Hendershott, Patric and Joel Slemrod. 1983. Taxes and the User Cost of Capital for OwnerOccupied Housing. Journal of the American Real Estate and Urban Economics Association. 10(4): 375-393. 
Jones, Lawrence. 1989. Current Wealth and Tenure Choice. Journal of the American Real Estate and Urban Economics Association. 17: 7-40.

Killingsworth, Mark. 1983. Labor Supply. Cambridge University Press, Cambridge.

LaFayette, William, Donald Haurin, and Patric Hendershott. 1995. Endogenous Mortgage Choice, Borrowing Constraints, and Tenure Choice. NBER Working Paper 5074.

Linneman, Peter and Susan Wachter. 1989. The Impacts of Borrowing Constraints on Homeownership. Journal of the American Real Estate and Urban Economics Association. 17(4): 389-402.

Muth, Richard and Allen Goodman. 1989. The Economics of Housing Markets. Harwood Academic Press, New York.

Rosen, Harvey. 1985. Housing Subsidies: Effects on Decisions, Efficiency, and Equity. In A.J. Auerbach and M. S. Feldstein, editors, Handbook of Public Economics, 1. North-Holland: 375420.

Zorn, Peter. 1989. Mobility-Tenure Decisions and Financial Credit: Do Mortgage Qualification Requirements Constrain Homeownership? Journal of the American Real Estate and Urban Economics Association. 17(4): 1-16. 
1. Transaction costs, including high search and information costs, and the difficulty of incrementally changing consumption, prevent households from adjusting housing quantity instantaneously in response to changing demand (Muth and Goodman 1989).

2. LaFayette, Haurin, and Hendershott (1995) define the amount of wealth available for a down payment as total wealth less one month of salary, pension investments, consumer durables, closing costs, and mortgage points. This approach suggests that L-W's moderate wealth constraint indicator equals unity when a household is constrained by "available" wealth, assuming that $10 \%$ of wealth is described by the list of alternative uses.

3. Similar comments apply to current income and the lender imposed income constraint.

4. The first step of the procedure is to estimate a probit model of which households are included in the sample of unconstrained owners. From this estimation, an inverse Mills ratio $(\lambda)$ is created and inserted in the housing demand equation. The significance level of $\lambda$ is only 0.3 ; thus there is no evidence of selection bias in this sample.

5. L-W determine permanent income using the human capital model of Goodman and Kawai (1982). Explanatory variables include highest grade completed, age of head of household, family size and the three squares of these terms. Also included are dummy variables for head being male or Black. We replicate their approach except that our estimation allows for a random household specific stochastic error in our panel data. All coefficients are significant with the expected sign except for family size.

The owner cost is: $P\left(\left(1-\tau_{y}\right) i+d+\left(1-\tau_{y}\right) \tau_{p}-\pi^{e}\right)$ where $P$ is the local real constant-quality house price index, $i$ is the interest rate, $d$ is the depreciation and maintenance rate, $\tau_{y}$ is the marginal income tax rate, $\tau_{p}$ is the local property tax rate, and $\pi^{\mathrm{e}}$ is expected house price inflation. The source of house prices was described previously, interest rates fell from 0.124 in 1985 to 0.101 in 1990 , depreciation and maintenance equal 0.035 annually, and expected house price inflation is 0.04 . Property taxes vary by state and the marginal tax rate is calculated by the NBER TAXSIM program for years 1985 to 1990 . We thank Daniel Feenberg for his assistance in calculating the marginal tax rates.

6. The method is described in detail in LIMDEP version 6.0, pp. 298-312.

7. Wealth continues to be the (slightly) more binding constraint, the evidence being that after LTV optimization, only $30 \%$ of households face a binding income constraint while $37 \%$ face a binding wealth constraint. This difference occurs because $7 \%$ of households reach the maximal LTV allowed (0.95). As expected, there are no households constrained only by income after the LTV is optimized.

8. Comparison with L-H-H (1995) is difficult because they allow for choice of mortgage among FHA FRMs and conventional FRMs and ARMs. 
9. The correct measure of the relative cost of owning compared to renting is the ratio of owner costs to renter costs. The owner cost measure differs from that used in the estimation of housing demand because the marginal tax rate is replaced by the tenure choice tax rate (Hendershott and Slemrod, 1983). The tenure choice tax rates were calculated using NBER's TAXSIM program. Our rental cost variable is from Coldwell Banker and it measures the rental cost of a constant-quality dwelling unit in a large number of MSAs. However, the Coldwell Banker sample of MSAs is $25 \%$ less than the Freddie Mac-Fannie Mae house price sample. Estimation using the larger sample and owner costs (based on the tenure choice tax rate) produces very similar results to estimates based on the smaller sample using the relative cost of owning. We report results from the larger sample because most of the variation in the relative price ratio is due to variation in real house prices, not in rents (Capozza, Hendershott and Green, 1996).

10. The advantage of their model is that it is relatively easy to estimate. The disadvantage is that the correlation is the same from period to period.

11. We create expected length of tenancy using L-W's method.

12. We do not list L-W's results because logit specifications yields coefficients that differ from probit models, although marginal effects can be compared.

13. The Chi-squared test of the reduction in log-likelihood yields a value of 637 . With one degree of freedom, this is significant at the 0.001 level.

14. If both wages equal $\$ 8.30$ hourly, the predicted probability of ownership is 0.35 if unconstrained, the same as the sample mean in L-W. If the household is constrained, the probability of ownership falls to 0.21 , a $40 \%$ reduction. In contrast, $\mathrm{L}-\mathrm{W}$ report that highly constrained households (either income or wealth) were $20 \%$ less likely to own implying a reduction in ownership rates from 0.35 to 0.28 . 
Table 1: Means of Variables

\begin{tabular}{|c|c|c|c|}
\hline Variables & Mean & Variables & Mean \\
\hline Permanent Income & 2.23 & Ownership Rate & 0.18 \\
\hline Relative Cost of Owning & 0.98 & Family Size & 2.72 \\
\hline Expected Length of Tenancy & 11.22 & $\mathrm{R} /$ Test Score & 4.19 \\
\hline Income Gap-High & 0.17 & House Value** & 5.41 \\
\hline Income Gap-Moderate & 0.04 & R/Male & 0.44 \\
\hline Income Gap-\$Shortage & 0.20 & R/Bad Health & 0.03 \\
\hline Wealth Gap-High & 0.64 & House Price index & 8.45 \\
\hline Wealth Gap-Moderate & 0.03 & Parent's Education & 11.42 \\
\hline Wealth Gap-\$Shortage & 1.40 & Log Owner Cost & 8.80 \\
\hline Gifts From Relatives & 0.22 & Respondent Wage & 6.26 \\
\hline Black & 0.32 & Spouse Wage & 7.21 \\
\hline Hispanic & 0.17 & Central City & 0.28 \\
\hline R/Age & 26.64 & Suburbs & 0.30 \\
\hline S/Age & 27.78 & In Other Part of MSA & 0.39 \\
\hline Married & 0.37 & Northeast & 0.19 \\
\hline Years Married* & 3.43 & North Central & 0.35 \\
\hline R/Highest Grade Completed & 12.41 & West & 0.20 \\
\hline S/Highest Grade Completed & 12.14 & & \\
\hline
\end{tabular}

Notes: $\mathrm{R}$ indicates the respondent, $\mathrm{S}$ indicates the spouse. Permanent income, relative cost, the two $\$$ shortage gap variables, the constant-quality house price index, and house value are in tens of thousands of dollars. House value is the mean for only those who own homes. Years married and all spouse means are for only married respondents. 
Table 2: Comparison of Estimates of the Percentage of Households Constrained by Mortgage Lender Income and Wealth Requirements

\begin{tabular}{|l|c|c|c|}
\hline Constraint & $\begin{array}{c}\text { L-W } \\
1981-83\end{array}$ & $\begin{array}{c}\text { H-H-W } \\
1985-90\end{array}$ & $\begin{array}{c}\text { H-H-W } \\
1985-90\end{array}$ \\
\hline \hline Income Gap-High & $27 \%$ & $28 \%$ & $\ldots--$ \\
\hline Wealth Gap-High & $40 \%$ & $58 \%$ & $-\cdots$ \\
\hline Minimized Gap-High & ---- & $-\cdots$ & $37 \%$ \\
\hline Income Gap-Moderate & $6 \%$ & $4 \%$ & $\cdots$ \\
\hline Wealth Gap-Moderate & $1 \%$ & $5 \%$ & ---- \\
\hline Minimized Gap-Moderate & ---- & ---- & $6 \%$ \\
\hline
\end{tabular}

Note: L-W is Linneman and Wachter (1989), H-H-W is this study. 
Table 3: Comparison of Linneman-Wachter and Haurin-Hendershott-Wachter Tenure Choice Estimation Results

\begin{tabular}{|c|c|c|c|c|}
\hline Variables & Pfledicted & I-W 1975-77 & L-W 1981-83 & $\begin{array}{l}\text { H-H-W 1985-90 } \\
\text { Baseline Case }\end{array}$ \\
\hline Permanent Income & + & + N.S. & $+5 \%$ & $+10 \%$ \\
\hline Relative Cost of Owning & - & - N.S. & $-1 \%$ & $-\quad 1 \%$ \\
\hline Expected Length of Tenancy & + & - N.S. & + N.S. & $+1 \%$ \\
\hline Income Gap-High & - & $-1 \%$ & $-5 \%$ & $-5 \%$ \\
\hline Income Gap-Moderate & - & $-1 \%$ & N.S. & $-10 \%$ \\
\hline Income Gap-\$ Shortage & - & - N.S. & N.S. & + N.S. \\
\hline Wealth Gap-High & - & $-1 \%$ & $-5 \%$ & $-1 \%$ \\
\hline Wealth Gap-Moderate & - & $-1 \%$ & N.S. & $-1 \%$ \\
\hline Wealth Gap-\$ Shortage & - & + N.S. & $-1 \%$ & $-1 \%$ \\
\hline Black & - & N.S. & N.S. & $+5 \%$ \\
\hline Hispanic & - & N.S. & + N.S. & - N.S. \\
\hline Head Age & + & + see note & + see note & - N.S. \\
\hline Married & + & $+\quad 1 \%$ & $+\quad 10 \%$ & $+1 \%$ \\
\hline Family Size & + & $+\quad 1 \%$ & $+\quad$ N.S. & - N.S. \\
\hline
\end{tabular}

Note: $\mathrm{L}-\mathrm{W}$ include a series of seven age range dummy variables. In general, ownership tendencies rise as age increases and, if a single variable was included, it would likely be statistically significant. 
Table 4: Probit Estimation Results of Homeownership Tendencies

\begin{tabular}{|c|c|c|c|}
\hline Variables & Baseline & Extended Model & Random Effects \\
\hline Constant & $-1.51(5.3)$ & $-1.62(6.4)$ & $-4.95(10.0)$ \\
\hline Permanent Income & $0.17(1.7)$ & ---- & --- \\
\hline Respondent Wage & --- & $0.08(4.2)$ & $0.18(4.4)$ \\
\hline Spouse Wage & ---- & $0.06(3.0)$ & $0.09(2.0)$ \\
\hline Relative Cost of Owning & $-1.45(10.5)$ & $-1.27(10.5)$ & $-3.02(11.4)$ \\
\hline Expected Length of Tenancy & $0.21(3.8)$ & $0.04(0.7)$ & $0.23(2.4)$ \\
\hline Income Gap-High & $-0.33(1.9)$ & ---- & ---- \\
\hline Income Gap-Moderate & $-0.28(1.6)$ & --- & --- \\
\hline Income Gap-\$Shortage & $0.04(0.5)$ & --- & --- \\
\hline Wealth Gap-High & $-1.17(12.1)$ & --- & --- \\
\hline Wealth Gap-Moderate & $-0.99(5.9)$ & --- & $\cdots$ \\
\hline Wealth Gap-\$Shortage & $-0.11(3.5)$ & --- & ---- \\
\hline Minimized Gap-High & --- & $-0.54(4.9)$ & $-0.38(2.5)$ \\
\hline Minimized Gap-Moderate & --- & $-0.47(3.6)$ & $-0.55(3.3)$ \\
\hline Minimized Gap-\$Shortage & --- & $0.01(0.2)$ & $-0.13(0.2)$ \\
\hline Black & $0.28(2.0)$ & $-0.17(1.4)$ & $0.14(0.6)$ \\
\hline Hispanic & $-0.12(1.6)$ & $0.06(0.8)$ & $0.17(0.8)$ \\
\hline Head Age & $-0.02(0.7)$ & $0.03(1.5)$ & $0.07(1.9)$ \\
\hline Married & $0.56(6.5)$ & $0.41(3.5)$ & $0.63(2.9)$ \\
\hline Family Size & $-0.03(1.5)$ & $-0.01(0.9)$ & $-0.02(0.7)$ \\
\hline Rho & --- & --- & $0.73(14.0)$ \\
\hline Sample Size & 4206 & 4206 & 4206 \\
\hline Log-Likelihood & -1201 & -1517 & -1199 \\
\hline Significance Level & 0.000 & 0.000 & 0.000 \\
\hline
\end{tabular}

Notes: The probit model in column three treats wealth, thus the constraint variables as endogenous. The model includes random individual effects. Permanent income, relative cost, and the two $\$$ shortage gap variables are in tens of thousands of dollars. Head Age is a series of dummy variables in L-W. 
Table A-1: Estimation of Household Wealth and Desired House Value

\begin{tabular}{|c|c|c|c|c|}
\hline Variables & Log of House Value & $\begin{array}{l}\text { Log Respondent } \\
\text { Wage: Tobit }\end{array}$ & $\begin{array}{l}\text { Log Spouse } \\
\text { Wage: Tobit }\end{array}$ & Wealth \\
\hline Constant & $5.69(3.5)$ & --- & $-\cdots$ & $15.95(0.8)$ \\
\hline $\mathrm{R} / \mathrm{male}$ & $0.10(1.5)$ & $0.43(18.0)$ & $-2.14(3.1)$ & $3.73(3.3)$ \\
\hline R/Black & $0.26(2.4)$ & $-0.25(8.2)$ & $-0.10(1.3)$ & $25.32(2.8)$ \\
\hline R/Hispanic & $-0.27(3.2)$ & $-0.12(3.6)$ & $-0.17(2.3)$ & $-0.78(0.5)$ \\
\hline Married & $-0.24(2.2)$ & --.- & --- & $-16.17(4.3)$ \\
\hline Years Married & $\cdots$ & --- &.- & $1.24(4.9)$ \\
\hline Gifts From relatives & --- & --- & --- & $0.99(8.1)$ \\
\hline House Price Index & --- & $\cdots$ & --- & $0.07(0.4)$ \\
\hline Parents' Education & --- & --- & --- & $0.20(1.2)$ \\
\hline R/Highest Grade &.-- & $0.09(2.0)$ & --- & $-3.38(4.3)$ \\
\hline R/Age & $0.23(3.7)$ & $-0.04(1.5)$ & $-\cdots$ & $0.76(0.5)$ \\
\hline R/Test Score & $\ldots$ & $0.21(12.3)$ & -- & $1.02(1.4)$ \\
\hline R/Bad Health & --- & $-0.24(3.5)$ & --- & $-0.30(0.2)$ \\
\hline S/Highest Grade & --- & --- & $0.15(2.4)$ & $0.71(3.1)$ \\
\hline S/Age & $\cdots$ & $\cdots$ & $0.08(2.2)$ & $0.50(4.4)$ \\
\hline R/Age Squared & $-0.004(3.9)$ & $0.001(2.9)$ & --- & $-0.60(1.9)$ \\
\hline R/Test Score Squared & $-\ldots$ & $-0.02(10.3)$ & --- & $-0.08(1.2)$ \\
\hline R/Highest Grade² & --- & $-0.001(0.7)$ & --- & \\
\hline S/Age Squared & --- & $\cdots$ & $-0.001(1.1)$ & \\
\hline S/Highest Grade ${ }^{2}$ & $-\cdots$ & $\cdots$ & $-0.002(0.8)$ & \\
\hline R/Highest Grade-R/Age ${ }^{2}$ & $\cdots$ & $\cdots$ & --- & $0.01(5.5)$ \\
\hline Black-R/Male & $\cdots$ & --- & $\cdots$ & $-1.07(0.5)$ \\
\hline Black-R/Age & --- & --- & $\ldots$ & $-1.19(0.3)$ \\
\hline Black-R/Highest Grade & -- & --- & --- & $0.28(0.5)$ \\
\hline Black-R/Test Score & --- & --- & --- & $-0.34(0.6)$ \\
\hline Black-S/Age & --- & $-\cdots$ & --- & $0.08(0.3)$ \\
\hline Black-S/Highest Grade & --- & $-\cdots$ & $\cdots$ & $-0.58(1.3)$ \\
\hline Black-House Price & $\cdots$ & $--\cdot$ & $\cdots$ & $0.11(0.3)$ \\
\hline Log Owner Cost & $-0.04(0.3)$ & --- & --- & --- \\
\hline Family Size & $-0.01(0.4)$ & $\cdots$ & --- & -- \\
\hline Permanent Income & $0.09(8.0)$ & $\cdots$ & $\cdots$ & $\cdots$ \\
\hline Central City & $-0.47(2.7)$ & $\cdots$ & -- & --- \\
\hline
\end{tabular}




\begin{tabular}{|l|c|c|c|c|}
\hline Suburbs & $-0.23(1.3)$ & $\cdots$ & $\cdots$ & $\cdots$ \\
\hline In Other Part of MSA & $-0.22(1.3)$ & $\cdots$ & $\cdots$ & $\cdots$ \\
\hline Northeast & $-0.22(2.3)$ & $\cdots$ & $\cdots$ & $\cdots$ \\
\hline North Central & $0.04(0.5)$ & $\cdots$ & $\cdots$ & $\cdots$ \\
\hline West & $-0.18(2.0)$ & $\cdots$ & & \\
\hline & & & 4206 & 4206 \\
\hline Sample Size & 500 & 4206 & $\cdots$ & 0.21 \\
\hline R-Squared & 0.25 & $\cdots$ & $\cdots$ \\
\hline
\end{tabular}

Notes: The achievement test score in tens. Respondent variables are summarized as " $\mathrm{R} /$ " and spouse variables are " $\mathrm{S} /$ ". Interaction variables are denoted with a ".". 